\title{
The Influence of Leadership, Motivation and Work Stress on Turnover Intention of PT. BCA Finance Karawang Branch
}

\author{
Diki Nurdiansyah, Parwoto, and Ahmad Badawi Saluy
}

\section{ABSTRACT}

\begin{abstract}
Human resources in a corporate organization is a unity that can not be separated to achieve organizational goals. The achievement of organizational goals can be seen from the performance of employees. Currently, the problem of high turnover intention has become a serious problem for many companies. The negative impact that is felt due to the occurrence of turnover intention in the company is on the quality and ability to replace employees who leave the company, so it takes time and new costs in recruiting new employees. Leadership is expected to be able to direct and motivate employees so that they can carry out their jobs well, and can control or reduce stress levels in employees. And can reduce the turnover rate can maximize employee performance. Therefore, based on the above background, this research takes the title "The Effect Of Leadership, Motivation And Work Stress On Turnover Intention Of Employees Of PT. XYZ Karawang Branch". This type of research uses a quantitative approach, with a sample of 51 respondents with a sample collection technique that is saturated sampling technique. Evaluation of the Measurement Model (Outer Model) and Evaluation of the Structural Model (Inner Model) to test and prove the research hypothesis. The results of this study indicate that leadership and motivation have no significant effect on turnover intention, while work stress has a significant positive effect on turnover intention. In order to reduce the turnover rate, it is hoped that the leadership will provide an appropriate job description for each employee so that there is no oversize capacity on the ability and working hours of employees.
\end{abstract}

Keywords: Job Stress, Leadership, Motivation, Turnover Intention.

\author{
Submitted : July 30, 2021 \\ Published : August 21, 2021 \\ ISSN: $2507-1076$ \\ DOI: $10.24018 / \mathrm{ejbmr} .2021 .6 .4 .1008$ \\ Diki Nurdiansyah* \\ Mercu Buana University, Jakarta, Indonesia \\ (e-mail: dikinu29@gmail.com) \\ Parwoto \\ Mercu Buana University, Jakarta, Indonesia. \\ (e-mail: parwoto.parwoto@mercubuana.ac.id) \\ Ahmad Badawi Saluy \\ Mercu Buana University, Jakarta, Indonesia. \\ (e-mail: ahmad.badawi@mercubuana.ac.id)
}

*Corresponding Author

\section{INTRODUCTION}

The financial sector is a group of service industry companies that have been included in public companies listed on the Indonesia Stock Exchange and are divided into several sub-sectors, including banking sub-sectors, financial institutions sub-sectors, securities companies sub-sector, insurance sub-sector and other sub-sector which is a company that produces raw materials totaling 1 company. To insert images in the financial sector, especially banking, has a very vital role in maintaining economic stability in a country. In addition to having a purpose as a provider of funds for those who have excess funds and those who lack funds, banking as a company also has another goal, namely maximizing the value of the company which can be reflected in the price of its shares.

Human resources in a company organization is an inseparable unit. As is known in the organization there is one element, namely humans, who are the driving force for the goals of an organization and play the most role in determining the success or failure of the organization's goals.

Currently, the problem of high turnover intention has become a serious problem for many companies. The negative impact that is felt due to the occurrence of turnover intention in the company is on the quality and ability to replace employees who leave the company, so it takes time and new costs in recruiting new employees.

TABLE I: EMPLOYEE TURNOVER DATA

\begin{tabular}{cccccc}
\hline \hline Year & $\begin{array}{c}\text { Total } \\
\text { Employees }\end{array}$ & $\begin{array}{c}\text { Employee } \\
\text { in }\end{array}$ & $\begin{array}{c}\text { Employee } \\
\text { out }\end{array}$ & Tolerance & Actual \\
\hline 2017 & 57 & 8 & 10 & $10 \%$ & $17 \%$ \\
2018 & 55 & 9 & 9 & $10 \%$ & $16 \%$ \\
2019 & 56 & 10 & 10 & $10 \%$ & $17 \%$ \\
2020 & 51 & 8 & 9 & $10 \%$ & $17 \%$ \\
\hline \hline
\end{tabular}

The number of employees leaving PT BCA Finance Karawang from 2017 to 2020 appears that the employee turnover rate is quite high. The annual turnover rate always exceeds $10 \%$. This is an indication of a problem that must be brought to the attention of management.

In addition to turnover data, the authors also conducted a pre-survey of 20 employees of PT BCA Finance Karawang, in order to find out what factors influence turnover intention, which are as follows: 


\section{A. Leadership}

Based on the results of the pre-survey related to leadership, it can be stated that the leader has not been able to coordinate subordinates well, has not become a problem solver in dealing with every challenge and work obstacle faced by employees, and is considered unable to become a role model for subordinates.

TABLE II: LEADERSHIP PRE-SURVEY

\begin{tabular}{|c|c|c|c|}
\hline No & Statement & Yes & Not \\
\hline 1. & $\begin{array}{l}\text { My boss always coordinates well with } \\
\text { employees }\end{array}$ & 8 & 10 \\
\hline 2. & $\begin{array}{l}\text { Superiors and subordinates are } \\
\text { directly involved in problem-solving }\end{array}$ & 9 & 9 \\
\hline \multirow[t]{2}{*}{3.} & $\begin{array}{l}\text { Bosses can be role models for } \\
\text { subordinates }\end{array}$ & 10 & 10 \\
\hline & Total average & $28.3 \%$ & $71.7 \%$ \\
\hline
\end{tabular}

\section{B. Motivation}

TABLE III: MOTIVATION PRE-SURVEY

\begin{tabular}{cccc}
\hline \hline No & Statement & Yes & Not \\
\hline 1. & $\begin{array}{c}\text { I am always enthusiastic and } \\
\text { motivated by my boss and coworkers } \\
\text { Wages/salaries given are in }\end{array}$ & $25 \%$ & 10 \\
2. & $\begin{array}{c}\text { accordance with the workload given } \\
\text { I was given the opportunity to take } \\
\text { 3. }\end{array}$ & $45 \%$ & 9 \\
& $\begin{array}{c}\text { part in a career development program } \\
\text { Total average }\end{array}$ & $38.3 \%$ & $61.7 \%$ \\
\hline \hline
\end{tabular}

Based on the results of the pre-survey related to motivation, it can be stated that there is no positive encouragement or motivation either from direct superiors or co-workers, the workload given is deemed not commensurate with the salary received, and opportunities for quality improvement are felt to be obtained easily and evenly.

\section{Work Stress}

TABLE IV: PRE-SURVEY OF WORK STRESS

\begin{tabular}{clcc}
\hline \hline No & Statement & Yes & Not \\
\hline 1. & $\begin{array}{l}\text { I feel the workload given is in } \\
\text { accordance with the time given }\end{array}$ & $35 \%$ & $65 \%$ \\
2. & I do work according to jobdesk & $45 \%$ & $55 \%$ \\
3. & $\begin{array}{l}\text { The pressure given is in accordance } \\
\text { with the target deadline }\end{array}$ & $55 \%$ & $55 \%$ \\
$\quad$ Total average & $41.7 \%$ & $58.3 \%$ \\
\hline \hline
\end{tabular}

Based on the results of the pre-survey related to work stress, it can be stated that the workload given is not in accordance with the time allotted, sometimes employees do work outside their job desk, and employees feel that there is the pressure given to work that must be completed quickly.

One of the factors that can reduce turnover intention is the way the leader must direct and motivate employees when carrying out work in order to reduce the feeling of being lazy to work such as delaying work so that employees can complete work on time.

Leadership is expected to be able to direct and motivate employees so that they can carry out their jobs well, and can control or reduce stress levels in employees. And can reduce the turnover rate can maximize employee performance.

\section{LITERATURE REVIEW}

\section{A. Leadership}

Leadership is the ability to direct followers to work together with confidence and diligently carry out the tasks assigned by their leaders.

\section{B. Motivation}

Motivation is a process that describes the intensity, direction, and persistence of an individual to achieve a goal.

\section{Work Stress}

Job stress is a feeling that suppresses or feels pressured by employees in dealing with work. Work stress is characterized by symptoms including unstable emotions, feeling uneasy, being alone, having trouble sleeping, not being able to relax, being anxious, tense, and nervous.

\section{Turnover Intention}

Turnover Intention is an employee's behavior that has a close relationship with the desire to leave his job, there are many reasons that cause this turnover intention, and one of them is the desire to get a better job.

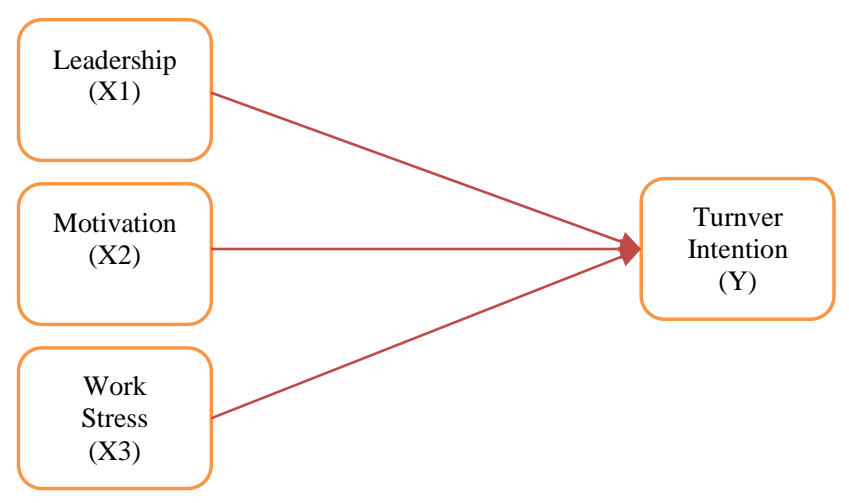

Fig. 1. Framework

\section{Methodology}

\section{A. Types of Research}

This study uses a quantitative approach method. According to Widodo (2017: 68), it is a series of research that starts from a number of theories and then is dedicated to a hypothesis and assumptions of a framework that is described in an analysis, which consists of variables that will lead to the operationalization of the concept.

\section{B. Population and Sample}

In this study, the sampling technique used is the saturated sampling technique, which is a sampling technique when all members of the population are used as samples.

\section{Methods and Analysis}

This study uses SEM (Structural Equation Model) analysis with SmartPLS3 which aims to determine whether there is an influence of the independent variable on the dependent variable. The evaluation of the model in PLS consists of two stages, namely the evaluation of the outer model or measurement model and the evaluation of the inner model or structural model (structural measurement). Evaluation of the measurement model is grouped into an evaluation of the reflective and formative models. 


\section{RESUlts AND DisCUSSIONS}

\section{A. Evaluation of the Measurement Model (Outer Model)}

\section{1) Convergent Validity}

The convergent validity test is carried out by checking, among others, individual item reliability, internal consistency, or construct reliability, and average variance extracted. Evaluation of convergent validity from individual item reliability checks can be seen from the standardized loading factor value. The standardized loading factor describes the magnitude of the correlation between each measurement item (indicator) and its construct.

The loading factor value used in this study is $>0.5$ so that if the loading factor value is $<0.5$ in the calculation results of the measurement model (outer model) it will be removed from the model. all indicators on the variables of leadership, motivation, work stress, and turnover intention already have a loading factor $>0.50$ which means that all indicators are valid in the measurement model.

The evaluation of convergent validity from the Average Variance Extracted (AVE) examination illustrates the magnitude of the variance or diversity of manifest variables that can be owned by the latent construct, the greater the variance or diversity of manifest variables that can be contained by the latent construct, the greater the representation of the manifest variable on the latent construct.

\begin{tabular}{cc} 
TABLE V: AVERAGE VARIANCE EXTRACTED (AVE) VALUE \\
\hline \hline Variable & $\begin{array}{c}\text { Average Variance Extracted } \\
\text { (AVE) Value }\end{array}$ \\
\hline Leadership & 0.540 \\
Motivation & 0.592 \\
Work Stress & 0.545 \\
Turnover Intention & 0.623 \\
\hline \hline
\end{tabular}

AVE values for all variables have AVE values $>0.5$, which are 0.540 for leadership, 0.592 for motivation, 0.545 for work stress, and 0.623 for turnover intention.

The evaluation of convergent validity from internal consistency reliability checks can be seen from the Cronbach's Coefficient Alpha and Composite Reliability (CR) values.

TABLE VI: CRONBACH'S COEFFICIENT ALPHA AND COMPOSITE RELIABILITY (CR) VALUES

\begin{tabular}{ccc}
\hline \hline Variable & $\begin{array}{c}\text { Cronbach's } \\
\text { Coefficient Alpha }\end{array}$ & $\begin{array}{c}\text { Composite } \\
\text { Reliability (CR) }\end{array}$ \\
\hline Leadership & 0.891 & 0.913 \\
Motivation & 0.922 & 0.935 \\
Work Stress & 0.788 & 0.846 \\
Turnover Intention & 0.931 & 0.942 \\
\hline \hline
\end{tabular}

Cronbach's Coefficient Alpha and composite reliability values for the variables studied, namely leadership, motivation, work stress, and turnover intention are more than 0.6 or even close to 1 . This value has exceeded the standard, namely $>0.6$ and $>0.7$, so all variables in the study declared reliable.

\section{2) Discriminant Validity}

Discriminant validity is by checking the value of cross loading, namely the correlation coefficient of the indicator to the construct compared to the correlation coefficient with other constructs.
All indicators on the variable constructs of leadership, motivation, work stress and turnover intention have a cross loading value that is greater than the cross loading value of other constructs.

\section{B. Evaluation of the Structural Model (Inner Model)}

Evaluation of the structural model (inner model) or hypothesis testing in this study through the steps of evaluating the path coefficient value, evaluating the $\mathrm{R} 2$ value, validating the overall structural model with the Goodness of Fit Index $(\mathrm{GoF})$, and testing predictive relevance (Q2).

\section{1) Evaluation of Path Coefficient Value (Path Coefficient)}

Evaluating the value of the path coefficient, based on the results of calculations using the calculate SmartPLS version 3.0 bootstrapping, the results obtained are path coefficients that describe the strength of the relationship between constructs/variables.

TABLE VII: PATH COEFFICIENT TESTING RESULTS

\begin{tabular}{|c|c|c|c|c|c|}
\hline Variable & $\mathrm{O}$ & M & STDEF & O-STDEV & $\begin{array}{c}\text { P- } \\
\text { Values }\end{array}$ \\
\hline $\begin{array}{c}\text { Leadership (X1) - } \\
>\text { Turnover } \\
\text { Intention (Y) }\end{array}$ & -0.135 & -0.088 & 0.167 & 0.806 & 0.420 \\
\hline $\begin{array}{c}\text { Motivation (X2) - } \\
>\text { Turnover } \\
\text { Intention (Y) }\end{array}$ & -0.034 & -0.042 & 0.159 & 0.212 & 0.832 \\
\hline $\begin{array}{c}\text { Work Stress (X3) } \\
\text {-> Turnover } \\
\text { Intention (Y) }\end{array}$ & 0.803 & 0.798 & 0.148 & 5,431 & 0.000 \\
\hline
\end{tabular}

a) The path coefficient is -0.135 with $\mathrm{T}_{\text {statistic }}(0.806)<\mathrm{T}_{\text {table }}$ (2.011) and p-values of $0.420>0.05$, thus Leadership has no significant effect on Turnover Intention.

b) The path coefficient is -0.034 with $\mathrm{T}_{\text {statistic }}(0.212)<\mathrm{T}_{\text {table }}$ (2.011) and $p$-values is $0.832>0.05$, thus motivation has no significant effect on Turnover Intention.

c) The path coefficient is 0.803 with $\mathrm{T}_{\text {statistic }}(5.431)>\mathrm{T}_{\text {table }}$ (2.011) and p-values are $0.000<0.05$, thus H3 is accepted. The result is that work stress has a significant effect on turnover intention.

\section{2) R2. Value Evaluation}

To evaluate the value of $\mathrm{R} 2$ based on the results of calculations using Calculate SmartPLS version 3.0, the result is that the R2 value is 0.506 , this means that $50.6 \%$ of the endogenous variables (turnover intention) can be explained by exogenous variables (leadership, motivation and work stress), while the remaining $49,4 \%$ can be explained by other variables outside of this research model.

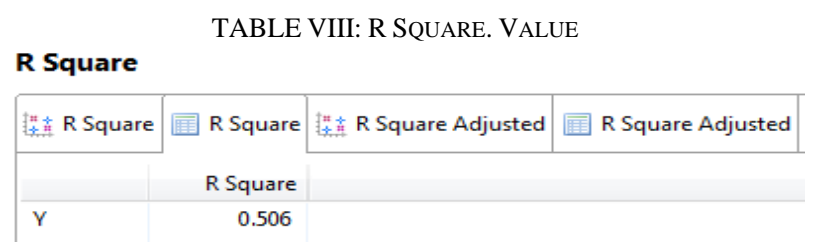

\section{3) Overall Structural Model Validation with Goodness of Fit Index (GoF)}

The purpose of testing the Goodness of Fit Index (GoF) is to validate the combined performance of the measurement model (outer model) and structural model (inner model) 
obtained through the following calculations:

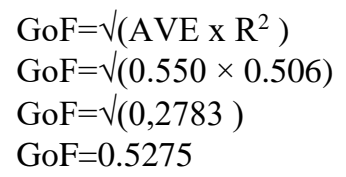

Information :

$\mathrm{AVE}=(0.540+0.592+0.445+0.623) / 4=2.2 / 4=0.550$

$\mathrm{R}$ square $=0.506$

The results of the calculation of the Goodness of Fit Index (GoF) show a value of 0.5275 . Based on these results, it can be concluded that the overall performance of the measurement model (outer model) and structural model (inner model) is good because the Goodness of Fit Index (GoF) value is more than 0.25 (moderate or medium scale).

\section{4) Predictive Relevance Test (Q2)}

The purpose of testing predictive relevance $(\mathrm{Q} 2)$ is to validate the model. Based on the results of calculations using SmartPLS version 3.0, the results of the Q2 value are 0.286.

TABLE IX: PREDICTIVE RELEVANCE (Q2)

\begin{tabular}{|c|c|c|c|c|c|c|c|}
\hline \multirow[t]{2}{*}{ Total } & 圆 Casel & 囯 Case2 & 国 Case3 & Case4 & 囯 Case5 & 圆 Case6 & Case7 \\
\hline & \multicolumn{2}{|c|}{ sSO } & SSE & \multicolumn{2}{|c|}{$Q\urcorner \leq(=1-S S E / S S O)$} & & \\
\hline $\mathrm{X} 1$ & 459.000 & \multicolumn{4}{|c|}{459.000} & & \\
\hline X2 & 510.000 & \multicolumn{2}{|c|}{510.000} & & & & \\
\hline X3 & 357.000 & \multicolumn{2}{|c|}{357.000} & & & & \\
\hline$Y$ & 510.000 & \multicolumn{2}{|c|}{363.964} & & 0.286 & & \\
\hline
\end{tabular}

5) Results of the Effect of Independent Variables on Dependent Variables

Testing the hypothesis about the effect of exogenous leadership variables (X1), motivation (X2) and work stress (X3) on the endogenous variable turnover intention (Y).

TABLE X: PATH CoEFFICIENT TESTING RESUltS

\begin{tabular}{cccccc}
\hline \hline Variable & $\mathrm{O}$ & $\mathrm{M}$ & STDEF & O-STDEV & $\begin{array}{c}\mathrm{P} \\
\text { Values }\end{array}$ \\
\hline $\begin{array}{c}\text { Leadership (X1) } \\
\quad>\text { Turnover } \\
\text { Intention (Y) } \\
\text { Motivation (X2) } \\
\quad>\text { Turnover } \\
\begin{array}{c}\text { Intention (Y) } \\
\text { Work Stress } \\
\text { (X3) - }\end{array}\end{array}$ & -0.135 & -0.088 & 0.167 & 0.806 & 0.420 \\
$>$ Turnover & 0.803 & -0.042 & 0.159 & 0.212 & 0.832 \\
Intention (Y) & & & & & \\
\hline \hline
\end{tabular}

a) Hypothesis 1 - Leadership has an effect on Turnover Intention.

The path coefficient is -0.135 with $\mathrm{T}_{\text {statistic }}(0.806)<\mathrm{T}_{\text {table }}$ (2.011) and p-values of $0.420>0.05$, thus $\mathrm{H} 1$ is rejected. The result is that Leadership has no significant effect on Turnover Intention.

b) Hypothesis 2 - Motivation has an effect on Turnover Intention.

The path coefficient is -0.034 with $\mathrm{T}_{\text {statistic }}(0.212)<\mathrm{T}_{\text {table }}$ (2.011) and p-values of $0.832>0.05$, thus $\mathrm{H} 2$ is rejected. The result is that motivation has no significant effect on Turnover Intention.

c) Hypothesis 3 - Job stress has an effect on turnover intention.

The path coefficient is 0.803 with $\mathrm{T}_{\text {Statistics }}(5.431)>\mathrm{T}_{\text {table }}$ (2.011) and p-values are $0.000<0.05$, thus H3 is accepted. The result is that work stress has a significant effect on turnover intention.

\section{Discussion}

1) The Effect of Leadership on Turnover Intention (Hypothesis 1)

The path coefficient value is -0.135 with $\mathrm{T}_{\text {Statistics }}(0.806)<$ $\mathrm{T}_{\text {table }}(1.991)$ and $\mathrm{p}$-values are $0.420>0.05$, thus $\mathrm{H} 1$ is rejected, it is concluded that leadership has no significant effect on turnover intention.

2) 2). The Effect of Motivation on Turnover Intention (Hypothesis 2)

The path coefficient value is -0.034 with $\mathrm{T}_{\text {Statistics }}(0.212)<$ $\mathrm{T}_{\text {table }}(1.991)$ and $\mathrm{p}$-values are $0.832>0.05$, thus $\mathrm{H} 2$ is rejected, it is concluded that motivation has no significant effect on turnover intention.

3) The Effect of Job Stress on Turnover Intention (Hypothesis 3)

The path coefficient value is 0.803 with $\mathrm{T}_{\text {Statistics }}(0.5431)<$ $\mathrm{T}_{\text {table }}(1.991)$ and $\mathrm{p}$-values are $0.000>0.05$, thus $\mathrm{H} 3$ is accepted, it is concluded that work stress has a significant effect on turnover intention. That is, the higher the level of employee work stress, the higher the level of turnover intention

\section{CONCLUSION AND SUGGESTION}

\section{A. Conclusion}

Based on the results of research related to the influence of leadership, motivation and work stress on turnover intention. The following are some conclusions obtained from the results in this study.

\section{1) Leadership partially has no effect on turnover} intention

This conclusion is shown by the $\mathrm{X} 1.3$ indicator which states "The leader manages working time according to the target", where the indicator is more dominant than other indicators. So this means that the leadership is good enough in managing any given work.

2) Motivation partially has no effect on turnover intention

This conclusion is shown by the X2.4 indicator which states "I always prioritize work." where the indicator is more dominant than other indicators. So this means that employees are quite responsible for the work that has been given.

\section{3) Job stress partially affects turnover intention}

This conclusion is shown by the X3.1 indicator which states "I feel that my workload is very heavy" where this indicator is more dominant than other indicators. This means that employees feel the workload that is borne is quite high.

\section{B. Suggestion}

Based on the conclusions of the research described above, 
a number of authors' suggestions that are implementable that can be applied to reduce the high turnover intention are as follows:

1. It is recommended to the leadership of PT. XYZ Karawang Branch in order to provide an appropriate job description to each employee so that there is no oversize capacity on the ability and working hours of employees so that employees do not feel there is excessive pressure that can cause work stress. This is shown by the results of the strongest indicator which states that "Fulfillment of work demands causes increased pressure", meaning that there are inappropriate work demands, causing pressure and heavy burdens beyond the ability of employees This can be done, among others, by providing resources that are in accordance with their abilities and capacities so that there is no long and tiring workload, no role conflict, and no ambiguity in the roles of each employee. Supported by the next strongest indicator which states that "I feel that the salary is not commensurate with the workload" meaning that there is a discrepancy in the salary or wages given to the workload received by the employee. This can be done by adjusting the amount of salary given to the workload that must be completed.

2. Based on the results and findings in this study, it is hoped that further researchers can examine other constructs that can contribute to the decrease in turnover rates. For example, compensation, job satisfaction, organizational culture and workload on turnover intention. This is expected to be able to provide positive input or contribution to the management and the academic world in general.

\section{REFERENCES}

[1] A.R. Elangovan, 2015, "Causal ordering of stress, satisfaction and commitment, and Intention to quit: a structural equations analysis", Leadership \& Organization Development Journal, Vol. 22, Iss 4, pp. $159-165$.

[2] Ahmad Badawi Saluy, Dian Ekowati, 2018, "The Influence of Motivation, Compensation, Work Satisfaction on Turnover Intention Nurse at JTS Hospital", Saudi Journal of Business and Management Studies, ISSN 2415-6663, pp 641-652.

[3] Anders Dysvik Bård Kuvaas, 2015, "Exploring the relative and combined influence of mastery-approach goals and work intrinsic motivation on employee Turnover Intention", Personnel Review, Vol. 39, Iss 5, pp.622-638.

[4] Annisa Falakha1, Parwoto, 2020, "Pengaruh Stres Kerja Dan Kepuasan Kerja Terhadap Turnover Intention Karyawan Outsourcing (Studi Pada Pt. Trifa Sari Nusantara)", Jurnal Ilmiah MEA (Manajemen, Ekonomi, dan Akuntansi), P-ISSN; 2541-5255, Vol. 4, No. 3, hal 1818-1830.

[5] Aulia Putri, 2017, "Pengaruh Ketidaamanan Kerja, Kepuasan Kerja dan Motivasi Kerja Terhadap Turnover Intention", Lembaga Penelitian, Pengembangan Pembelajaran dan Pengabdian Kepada Masyarakat, ISSN:2598-0246, Vol. 229-244.

[6] Byoung-kwon Lee, et al, 2016, "Impact of work environment and work-related stress on Turnover Intention in physical therapists", $J$. Phys. Ther. Sci. 28: 2358-2361.

[7] Chieh-Peng Lin Min-Ling Liu, 2017, "Examining the effects of corporate social responsibility and ethical leadership on Turnover Intention", Personnel Review, Vol. 46, Iss 3.

[8] Firda Widiawati, et al, 2017, "Pengaruh Beban Kerja, Stress Kerja Dan Motivasi Kerja Terhadap Turnover Intention Karyawan PT Geogiven Visi Mandiri Semarang", Fakultas Ekonomika \& Bisnis Universitas Pandanaran, Vol. 5, No. 8, hal 13-35.

[9] Gabriela R. Ngantung, et al, 2015, "The Effect of Job Stress, Workload and Work Environment on Employee Turnover (Case Study at PT Hasjrat Abadi Manado", Jurnal Berkala Ilmiah Efisiensi, Vol. 9, No. 1 , hal 44-53.
[10] Garazi Azanza, et al, 2015, "The effects of authentic leadership on Turnover Intention", Leadership \& Organization Development Journal, Vol. 36, Iss 8, hal 123-134.

[11] I Gede Diatmika Paripurna, et al, 2017, "Pengaruh Kepemimpinan Dan Kepuasan Kerja Terhadap Turnover Intention Serta Dampaknya Terhadap Kinerja Karyawan Pada PT Agung Automall Kuta”, E-Jurnal Ekonomi dan Bisnis Universitas Udayana, ISSN : 2337-3067.

[12] Janelle E. Wells Jon Welty Peachey, 2015, "Turnover Intentions Do leadership behaviors and satisfaction with the leader matter", Team Performance Management: An International Journal, Vol. 17, Iss 1/2, pp. $23-40$

[13] Jungin Kim, 2018, "The contrary effects of intrinsic and extrinsic motivation on burnout and Turnover Intention in the public sector", International Journal of Manpower, Vol. 20, pp. 24-41.

[14] Muhammad Irfan Nasution, 2015, "Pengaruh Stres Kerja, Kepuasan Kerja Dan Komitmen Organisasi Terhadap Turnover Intention Medical Representative”, Jurnal Ilmiah Manajemen, Vol. VII, No. 3, hal 4453.

[15] Muhammad Khaidir, Tinik Sugiati, 2015, "Pengaruh Stres Kerja, Kompensasi Dan Kepuasan Kerja Terhadap Turnover Intention Studi Pada Karyawan Kontrak PT. Gagah Satria Manunggal Banjarmasin”, Jurnal Wawasan Manajemen, Vol. 4, No. 3, hal 34-33.

[16] Nadia Nurfadilah, et al, 2018, "The Impact of Compensation And Leadership On The Organizational Commitment And The Implication On Employee's Turnover Intention Of PT. Provices Indonesia Central Office", International Humanities And Applied Sciences Journal, ISSN 2622-5808, Volume 1, Issue 1.

[17] Nanayakkara, A.K. et al, 2018, "Impact of Occupational Stress on Turnover Intention of Machine Operators in Selected Apparel Manufacturing Companies in Sri Lanka”, Human Resource Management Journal, Vol. 6, No. 1.

[18] Ni Made Tiya Jumani Monica, et al, 2017, "Pengaruh Stres Kerja, Komitmen Organisasional, Dan Kepuasan Kerja Terhadap Turnover Intention", E-Jurnal Manajemen Unud, Vol. 6, No. 3, hal 37-48.

[19] Raad Abdulkareem Shareef, et al, 2018, "The influence of ethical leadership on academic employees' organizational citizenship behavior and Turnover Intention: Mediating role of intrinsic motivation", Emerald Publishing Limited 0025-1747.

[20] Rabia Imran, et al, 2017, "Teacher's Turnover Intentions: examining the impact of motivation and organizational commitment", International Journal of Educational Management, Vol. 2, No. 9.

[21] Reseliani Mahrofi, et al, 2017, "Pengaruh Stres Kerja, Motivasi, Dan Lingkungan Kerja Terhadap Turnover Intention", $e-$ Jurnal Riset Manajemen Prodi Manajemen Fakultas Ekonomi Unisma, Vol. 10, hal 67-88.

[22] Saac Kosi, et al, 2015, "Teacher motivation and job satisfaction on Intention to quit: An empirical study in public second cycle schools in Tamale Metropolis, Ghana", Emerald Publishing Limited, Vol. 39, Iss 5, pp. 622-638, 2015.

[23] Sangeeta Sahu, et al, 2018, "Transformational leadership and turnover Mediating effects of employee engagement, employer branding, and psychological attachment", Emerald Publishing Limited, Vol. 39, No. 1 , pp. 82-99.

[24] Siti Noor Hidayati, 2018, "Pengaruh Kepemimpinan, Kompensasi, Komunikasi, dan Motivasi Kerja terhadap Turnover Intention Pegawai dengan Kepuasan Kerja sebagai Variabel Antara", Jurnal Maksipreneur, Vol. 7, No. 2.

[25] Syarief Iskandar, et al, 2015, "Pengaruh Kepemimpinan Terhadap Turn Over Intention Karyawan Departemen Front Office Di Hotel Ibis Bandung Trans Studio", Jurnal Manajemen Resort dan Leisure, Vol. 12, No. 2.

[26] Syeda Sania Zahra, et al, 2018, "The relationship between job stress and Turnover Intentions in the pesticide sector of Pakistan: An employee behavior perspective", Management Issues in Healthcare System, Vol. 34, No. 1-12.

[27] Tesha Jovi Amany, 2015, "Pengaruh Stres Kerja, Kepuasan Tingkat Gaji Dan Kepemimpinan Terhadap Turnover Intentions Staff Auditor Di Kantor Akuntan Publik (Studi Pada Kap Di Jakarta Dan Bandung)", JOM Fekon, Vol. 3, No. 1.

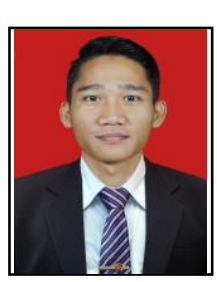

Diki Nurdiansyahis a student in the Faculty of Economics and Business Study Master of Management Program from Mercu Buana University, Jakarta, Indonesia. Concentration of Human Resource Management. 